\title{
STIMULATORY EFFECT OF THE WATER EXTRACT OF BAMBOO GRASS (FOLIN SOLUTION) ON GASTRIC ACID SECRETION IN PYLORUS-LIGATED RATS
}

\author{
Susumu OKABE, Koji TAKEUCHI, Keijiro TAKAGI \\ and Madoka SHIBATA* \\ Department of Chemical Pharmacology, Faculty of Pharmaceutical Sciences, \\ University of Tokyo, Bunkyo, Tokyo 113 and *Department of Pharmacology, \\ Hoshi Institute of Pharmaceutical Sciences, Shinagawa, \\ Tokyo 142, Japan
}

Accepted June 10, 1975

As one type of pharmacological analyses of a hot water extract of Bamboo Grass (Sasa Albomargrita) (Folin solution), the effect of the extract on gastric secretion was studied in the rat. Folin solution was separated into Lots 1 and 2: Lot 1 was extracted by hot water while Lot 2 was extracted by hot water in a pressure oven. The main component in both Lot 1 and 2 was confirmed as a polysaccharide, the molecular weight of which was less than 5,000 . The folin solution has a marked stimulatory effect on gastric acid sccretion in the rat.

Male Donryu strain rats, 180-210 g, were deprived of all solid food for $24 \mathrm{hr}$ but had free access to water. The pylorus was ligated under ether anesthesia according to the standard method by Shay et al. (1). Folin solution, either Lot 1 or 2, was given orally or intraduodenally $10 \mathrm{~min}$ after pylorus ligation in doses of $0.5,1.0$ or $1.5 \mathrm{~g} / \mathrm{kg}$; each volume was $0.5,1.0$ or $1.5 \mathrm{~m} / 200 \mathrm{~g}$ of body weight, respectively. Four hr after the administration of Folin solution, during which time no food and water was provided, the animals were sacrificed under ether anesthesia and the gastric contents were collected. The control animals were given the same amount of saline solution either orally or intraduodenally. After centrifugation, samples were analyzed for volume and titrated with $0.1 \mathrm{~N} \mathrm{NaOH}$ to $\mathrm{pH} 7.0$ (Hitachi $\mathrm{pH}$ meter) for titratable acidity, which is expressed as meq/1. The $\mathrm{pH}$ of Folin solution was 6.17 (Lot 1$)$ and $6.28(\operatorname{Lot} 2)$ and did not interfere with the acid titration with $\mathrm{NaOH}$ in the in vitro study. The pepsin activity was detcrmined by Anson's method (2), and was expressed as mg pepsin per ml. The level of significance was calculated by using Student's t-test.

It was revealed that an oral Folin solution, both Lot 1 and 2, produced a marked stimulation of gastric acid secretion at the dose level of 1.0 and $1.5 \mathrm{~g} / \mathrm{kg}$ as compared with the control. (Table 1). The increment of acid concentration in response to $1.5 \mathrm{~g}$ of Lot 1 or 2 was $37.3 \%$ or $40.7 \%$ as compared with the control value, respectively. Regarding the Lot 2 group, gastric acid secretion was significantly stimulated even at $0.5 \mathrm{~g} / \mathrm{kg}$. The gastric juice volume was not affected at all by the Folin solution, either Lot 1 or 2 . However, the pepsin activity was slightly but significantly stimulated by $0.5 \mathrm{~g} / \mathrm{kg}$ of Lot 1 and by 0.5 or $1.0 \mathrm{~g} / \mathrm{kg}$ of Lot 2 . In contrast, the intraduodenal administration of Folin solution neither 
TABLE 1. Effects of the water extract of Bamboo Grass (Folin solution) on gastric secretion in pylorus-ligated rats (24 hr fasting, $4 \mathrm{hr}$ ligation)

\begin{tabular}{|c|c|c|c|c|c|c|c|}
\hline \multirow{2}{*}{\multicolumn{2}{|c|}{ Treatment }} & \multirow{2}{*}{$\begin{array}{l}\text { Dose } \\
(\mathrm{g} / \mathrm{kg})\end{array}$} & \multirow{2}{*}{$\begin{array}{l}\text { No. of } \\
\text { rats }\end{array}$} & \multirow{2}{*}{$\begin{array}{l}\text { Volume } \\
(\mathrm{ml})\end{array}$} & \multicolumn{2}{|c|}{$\begin{array}{l}\text { Gastric Contents } \\
\text { Titratable acidity }\end{array}$} & \multirow{2}{*}{$\begin{array}{l}\text { Pepsin } \\
\text { (mg/ml) }\end{array}$} \\
\hline & & & & & $(\mathrm{meq} / 1)$ & ( $\%$ increment) & \\
\hline \multirow{12}{*}{$\begin{array}{l}\text { Folin } \\
\text { solution } \\
\text { (p.o.) }\end{array}$} & Saline & & 10 & $7.6 \pm 0.4$ & $117.8 \pm 4.0$ & & $19.9 \pm 1.0$ \\
\hline & Lot 1 & 0.5 & 10 & $7.8 \pm 0.7$ & $121.5 \pm 3.2$ & 3.1 & $22.9 \pm 0.7$ \\
\hline & Saline & & 10 & $9.1 \pm 0.6$ & $117.1 \pm 2.8$ & & $20.6 \pm 1.0$ \\
\hline & Lot 1 & 1.0 & 10 & $8.7 \pm 0.7$ & $134.8 \pm 2.3$ & $15.1 * *$ & $21.9 \pm 1.0$ \\
\hline & Saline & & 10 & $10.3 \pm 0.4$ & $109.4 \pm 2.4$ & & $20.6 \pm 0.5$ \\
\hline & Lot 1 & 1.5 & 10 & $9.9 \pm 0.6$ & $150.2 \pm 4.8$ & $37.3^{* *}$ & $21.9 \pm 0.9$ \\
\hline & Saline & & 10 & $6.0 \pm 0.6$ & $110.1 \pm 3.8$ & & $16.9 \pm 0.6$ \\
\hline & Lot 2 & 0.5 & 10 & $7.2 \doteqdot 0.6$ & $122.7 \pm 2.3$ & $11.4^{* *}$ & $21.0 \pm 0.4^{* *}$ \\
\hline & Saline & & 10 & $6.7 \pm 0.4$ & $106.2 \pm 3.4$ & & $18.7 \pm 0.4$ \\
\hline & Lot 2 & 1.0 & 10 & $7.1 \pm 0.5$ & $129.9 \doteq 1.9$ & $22.3^{* *}$ & $22.6 \pm 0.7^{* *}$ \\
\hline & Saline & & 10 & $8.7 \pm 0.4$ & $100.2 \doteq 4.0$ & & $22.3 \pm 0.9$ \\
\hline & Lot 2 & 1.5 & 10 & $8.7 \pm 0.3$ & $141.0 \pm 1.8$ & $40.7^{* *}$ & $21.7 \pm 0.7$ \\
\hline \multirow{3}{*}{$\begin{array}{l}\text { Folin } \\
\text { solution } \\
\text { (i.d.) }\end{array}$} & Saline & & 10 & $5.5 \pm 0.4$ & $109.2 \doteq 4.2$ & & $21.4 \pm 1.0$ \\
\hline & Lot 1 & 1.5 & 10 & $4.5 \pm 0.6$ & $110.6 \div 6.0$ & 1.3 & $23.3 \pm 2.8$ \\
\hline & Lot 2 & 1.5 & 10 & $5.7 \pm 0.6$ & $112.9 \pm 4.6$ & 3.4 & $22.1 \pm 1.1$ \\
\hline
\end{tabular}

All figures represent mean $t$ s.e. $* \mathbf{P}<0.05, \quad{ }^{* *} \mathbf{P}<0.001$

i.d. intraduodenally

Lot 1 or 2 produced any effect on gastric secretion at the dose of $1.5 \mathrm{~g} / \mathrm{kg}$. These facts indicate that Folin solution has to be present at least in the stomach to stimulate acid secretion in the rat. The reduction of gastric juice volume by the intraduodenal administration of saline solution was quite evident as compared with the volume by the oral route. This phenomenon indeed appears to be caused by a duodenal inhibitory mechanism with a relatively large amount of saline solution, as reported previously (3). Gastric secretory stimulants, such as histamine, gastrin, methacholine and pilocarpine, stimulate gastric acid secretion, which is usually accompanied by a considerable increment in gastric juice volume. To our knowledge, substances which exclusively stimulate the secretion of acid alone, without any appreciable side effect, have never becn reported. Several plant extracts such as FM $100(4,5)$, paeoniflorin $(6)$, platycodin $(7,8)$, genipin (9) revealed to inhibit gastric secretion in rats. Thus, Folin solution which stimulates acid secretion without affecting the gastric volume, appears to be a quite unique material. Further fractionation of Folin solution and pharmacological analysis are now under investigation.

\section{REFERENCES}

1) Sihay, H., Komarov, S.A., Fels, S.S., Mrranze, D., Grunstein, M. and Siplet, T.H.: Gastroenterology 5, 43 (1945); 2) Anson, M.L.: J. gen. Physiol. 22, 79 (1938); 3) OKane, S., Takeuchi, K., Nakamura, K. and Takagr, K.: Am. J. dig. Dis. 20, 138 (1975); 4) Takagi, K. AND IsHII, Y.: Arzneim.-Forsch. 17, 1544 (1967); 5) ISHII, Y.: Arzneim.-Forsch. 18, 53 (1968); 6) Takagi, K. And Harada, M.: Yakugaku Zasshi 89, 887 (1968) (in Japanese); 7) LeE, E.B. Yakugaku Zasshi 93, 1183 (1973) (in Japanese); 8) Kawashima, K., LeE, E.B., HiRaI, T., TAKeuchi, K. And Takagi, K.: Chem. Pharm. Bull. 20, 755 (1972); 9) Harada, M., Tenmyo, N., Aburada, M. And Endo. T.: Yalutgaku Zasshi 94, 157 (1974) (in Japanese) 